I. Baev, et al., Int. J. of Energy Prod. \& Mgmt., Vol. 3, No. 4 (2018) 277-291

\title{
IMPROVING THE EFFICIENCY OF USING SMALL- DISTRIBUTED GENERATION SYSTEMS THROUGH MECHANISMS OF DEMAND MANAGEMENT FOR ELECTRICITY AND GAS
}

\author{
IGOR BAEV, ANATOLIY DZYUBA, IRINA SOLOVYEVA \& NADEZHDA KUZMINA \\ South Ural State University, Russia.
}

\begin{abstract}
The article is devoted to the development of a model and a set of methods for improving the efficiency of using small-distributed generation systems. The basis of the developed model is the integration of methods of price-dependent demand management for electricity and natural gas with a system of small-distributed power generation. The developed management model allows electricity consumers to reduce the cost of purchasing energy resources in comparison with the cost of electricity supplied from energy companies, based on the analysis of price indicators for the supply of electricity from regional energy markets and the terms of natural gas supply. The article presents the results of the pricing principles analysis for all components of the electricity and natural gas cost. The possibility of complex price-dependent demand management for the consumption of electric power is demonstrated through the management of electricity generation schedules by a small-generation system and schedules of gas consumption spent on electricity generation by a system of small-distributed generation. The complex of methods of price-dependent power consumption developed by the authors, taking into account the use of the system of small-distributed generation, can be adapted to the use by various types of electricity consumers that purchase electricity in the energy markets of various countries of the world.

Keywords: Electric power industry, Energy efficiency, Energy market, Fuel and energy complex, Gas consumption, Modeling, Power consumption, Price-dependent consumption, Small-distributed power industry, Small generation.
\end{abstract}

\section{INTRODUCTION}

One of the basic components of the modern technological order of global economic system development is the improvement of energy conservation and energy efficiency, whose introduction at the level of national economies or individual large consumers of energy resources allows a qualitative leap in the stability of economic entities without the need of significant investment. The increase in the cost of hydrocarbon raw materials in the world energy markets, accompanied by the growth in world demand for energy resources, calls for drawing attention to the development of analytical, methodological papers in the field of improving energy efficiency.

Among the technologies that have received the greatest popularity among consumers of world energy resources, the use of autonomous resource systems of power supply, called small-distributed power systems [1,2], should be noted. During the last decade, the study of the use of a small-distributed generation system was pursued both in world [3-5] and Russian studies [6,7]. The latter consider autonomous power plants of medium capacity (up to 25 MW and/or $20 \mathrm{Gcal} / \mathrm{h}$ ) installed on the sites of electricity consumers and designed to generate electrical and/or thermal energy [8].

Advantages of using small-distributed generation systems are: the possibility of obtaining a lower cost electricity, compared to that supplied by energy companies due to a lower production cost, as well as elimination of the cost component for the transportation of electricity and the network losses due to the location of the power supply source being in close 
proximity to energy-consuming facilities. Depending on the cost of electricity supplied by energy companies in various countries around the world, the effect of using systems of small-distributed generation is significantly differentiated.

\section{RELEVANCE OF IMPROVING THE EFFICIENCY OF SMALL-DISTRIBUTED GENERATION SYSTEMS}

An urgent issue for world researchers in the field of application of small-distributed generation systems remains an increase in the economic efficiency of their use [9,10].

Operation of small-distributed generation systems allows to:

- reduce the average and marginal costs of paying for energy consumed by an enterprise;

- reduce the supplier's risk, that is, the dependence on external energy suppliers, through their own production;

- increase the efficiency of the energy consumers' main activity that use distributed generation systems.

One of the modern mechanisms that make the increase of the economic efficiency of electricity consumption possible is price-dependent consumption technology, which consists in managing the cost of purchasing energy resources by regulating the schedules of own demand for electricity and natural gas, taking into account market parameters $[11,12]$. The mechanism of price-dependent consumption of electric power and natural gas makes the reduction of the purchased energy resources unit cost possible without reducing the volume of their total consumption.

There is a possibility of flexible management of own energy demand for electricity consumers with small-distributed generation systems operating on natural gas and simultaneously purchasing part of the consumed electricity from energy companies.

\section{RESEARCH METHODOLOGY}

The use of a small-distributed generation system is advisable if the average tariff for electricity on the market is higher than the average cost of its own generation; the difference can be calculated using eqn (1) [13].

$$
\Delta E_{m}^{S D G}=V_{m}^{P S} / W_{m}^{P S}-V_{m}^{S D G} / W_{m}^{S D G}
$$

where $\Delta E_{m}^{S D G}$ is the difference between the cost of $1 \mathrm{kWh}$ of electricity on the market and the cost of its production by a system of small-distributed generation;

$V_{m}^{P S}$ - the cost of electricity purchased from energy companies for the settlement month;

$V_{m}^{S D G}-$ the cost of electricity generated by the small-distributed generation system for the settlement month (RUB);

$W_{m}^{P S}$ - the amount of electricity purchased from energy companies for the settlement month (kWh);

$W_{m}^{S D G}$ - the amount of electricity generated by the small-distributed generation system for the settlement month $(\mathrm{kWh})$. 
Thus, the effect of using systems of small-distributed generation is represented by $\Delta E_{m}$, which is the difference between the cost of electricity purchased in full from energy companies and the cost of electricity partially purchased and partially generated by the system of small-distributed generation.

This paper considers the situation when an enterprise already has small-distributed generation and does not require additional costs for its purchase and installation.

The cumulative effect of power generation using the small-distributed generation system $\Sigma_{m} E^{S D G}$ for a period is determined using eqn (2) (in RUB).

$$
\Sigma_{m} E^{S D G}=\Delta E_{m}^{S D G} \times W_{m}^{S D G}
$$

The average tariff for electricity consumption $\mathrm{T}_{m}$ for a period is determined using eqn (3) (in RUB/kWh).

$$
\mathrm{T}_{m}=\frac{V_{m}^{P S}+V_{m}^{S D G}}{W_{m}^{P S}+W_{m}^{S D G}}
$$

As can be seen from eqns (1), (2) and (3), the parameters $E_{m}^{S D G}, \Sigma_{m} E^{S D G}$ and $T_{m}$ depend both on the total cost of the generated and consumed electric power $V_{m}^{P S}$ and $V_{m}^{S D G}$, and on the ratio between the volumes produced and consumed electricity $W_{m}^{P S}$ and $W_{m}^{S D G}$.

Thus, using the mechanism of price-dependent power management in conjunction with the use of a distributed generation system allows us to reduce the average tariff for consumed electricity $\mathrm{T}_{m}$, and, consequently, the total cost of electricity consumption.

In the same manner, the method of price-dependent management can be applied in many countries of the world at enterprises that have systems of small-distributed generation.

Examples of applying the model of price-dependent electricity consumption management on the Russian market can be given. The electricity market of Russia was formed in the context of existing global mechanisms, such as NYISO, PJM, Nord Pool, Garabi, Siepac. In this regard, pricing mechanisms applied to the Russian electricity market are similar to those used in many countries of the world.

\subsection{Formulation of the cost of electricity purchase}

All electricity that is converted into Russia's power systems is sold and bought within the framework of electricity markets [15]. The final cost of electricity purchased by large consumers of electricity from the power system $\left(V^{P S}\right)$ consists of three main components as indicated by eqn (4) [14]:

$$
V^{P S}=V W+V P+V N
$$

where $V W$ is the cost of consumed electric energy (in RUB); $V P$, the electric capacity charge (in RUB) and $V N$, the cost of consumed electricity transmission services (rub.).

The description and calculation parameters of each component of the electricity cost are presented in Table 1.

Thus, the cost of electricity purchased from the power system for each settlement period depends on both the price parameters of the electricity market and the characteristics of its own demand volume and schedule for power consumption from the power system $W_{t}^{P S}$ as indicated by eqn (12) 
Table 1: Description and parameters of electricity cost components calculation.

\begin{tabular}{|c|c|c|}
\hline No. & Component & Description \\
\hline 1 & $\begin{array}{l}\text { Cost of elec- } \\
\text { tricity, eqn (5) }\end{array}$ & $\begin{array}{l}\text { It reflects the } \\
\text { unit costs of the } \\
\text { power system for } \\
\text { generating elec- } \\
\text { tricity at every } \\
\text { hour of the day }\end{array}$ \\
\hline 2 & $\begin{array}{l}\text { Cost of electric } \\
\text { capacity, eqn } \\
\text { (6) [16] }\end{array}$ & $\begin{array}{l}\text { It reflects the } \\
\text { payment of the } \\
\text { services cost by } \\
\text { the enterprise for } \\
\text { readiness to gen- } \\
\text { erate electricity } \\
\text { in the necessary } \\
\text { volume for the } \\
\text { enterprise in a } \\
\text { certain period of } \\
\text { time. }\end{array}$ \\
\hline
\end{tabular}

\begin{tabular}{|c|c|}
\hline $\begin{array}{l}\text { Cost of the } \\
\text { electricity } \\
\text { transmission } \\
\text { service, eqn (8) }\end{array}$ & $\begin{array}{l}\text { It reflects the } \\
\text { payment for } \\
\text { the provision of } \\
\text { power system } \\
\text { services for the } \\
\text { transportation of } \\
\text { electricity gener- } \\
\text { ated by power } \\
\text { plants to the final } \\
\text { consumers of } \\
\text { electricity }\end{array}$ \\
\hline
\end{tabular}

Formula for calculating the cost

$$
V W=\Sigma_{m}\left(W_{t}^{P S} \times P_{M D A}^{t}\right)
$$

where $W_{t}^{P S}$ is the hourly amount of electricity consumed from the power system $(\mathrm{kWh})$ and $P_{M D A}^{t}$, the market price for the day ahead (MDA) per hour (RUB/kWh)

$$
\mathrm{VP}=\mathrm{VP}_{\mathrm{m}} \times \mathrm{TP}_{\mathrm{m}}
$$

where $\mathrm{VP}_{\mathrm{m}}$ is the value of obligations for purchasing capacity (MW per month) given by

$$
\mathrm{VP}_{\mathrm{m}}=\Sigma_{\text {work,m }} \mathrm{W}_{\mathrm{t} \_ \text {max_region }}^{P S} / \mathrm{n}_{\text {work }, \mathrm{m}}
$$

$\mathrm{TP}_{\mathrm{m}}$ is the price of capacity purchased by the consumer in month $\mathrm{m}$ (RUB/MW per month) t_max_region is the time (in hours) of the combined maximum consumption of the regional energy system.

$\mathrm{n}_{\text {work,m }}$ is the number of working days in a month.

$$
\mathrm{t} \_ \text {max_region э T_max_SO }
$$

T_max_SO is the number of the intervals of the planned hours of the peak load of the energy system [17].

$$
\mathrm{VN}=\mathrm{VN} 2_{\mathrm{m}}^{\text {cont }}+\mathrm{VN} 2_{\mathrm{m}}^{\text {tech }}
$$

where $\mathrm{VN}_{\mathrm{m}}^{\text {cont }}$ is the cost of the service for the maintenance of electrical networks (RUB) given by

$$
\mathrm{VN} 22_{\mathrm{m}}^{\text {cont }}=\mathrm{T}_{\mathrm{m}}^{\mathrm{cont}} \times \mathrm{VN} 2_{\mathrm{m}}
$$

$\mathrm{VN} 2{ }_{\mathrm{m}}^{\text {tech }}$ is the cost of the service for payment of technological consumption (losses) in electrical networks for the settlement month, (RUB) given by

$$
\mathrm{VN} 2{ }_{\mathrm{m}}^{\mathrm{tech}}=\mathrm{T}_{\mathrm{m}}^{\mathrm{tech}} \times \Sigma_{\mathrm{m}} \mathrm{W}_{\mathrm{t}}^{P S}
$$

$\mathrm{T}_{\mathrm{m}}^{\mathrm{cont}}$ is the rate of the tariff for the maintenance of electric networks (RUB/kWh). $\mathrm{VN} 2{ }_{\mathrm{m}}$ is the value taken to calculate the obligation to pay for the maintenance of electrical networks in the settlement month (kWh) given by 


$$
\begin{gathered}
\mathrm{VN} 2_{\mathrm{m}}= \\
\Sigma_{\text {work, } \mathrm{m}} \max \left(W_{\mathrm{T} \_ \text {max_So }}^{P S}\right) / \mathrm{n}_{\text {work, } \mathrm{m}} .
\end{gathered}
$$

$\max \left(W_{\mathrm{T} \_ \text {max_So }}^{\mathrm{t}}\right)$ is the maximum value of electricity consumption during the period of planned hours of the peak load $(\mathrm{kW})$.

$\mathrm{T}_{\mathrm{m}}^{\mathrm{tech}}$ is the tariff rate for payment of technological consumption (losses) in electrical networks (RUB/kWh)

$$
V^{P S} \neq \text { const } ; V^{P S}=\left\{\begin{array}{l}
V W=f\left(W_{t}^{P S}\right) \\
V P=f\left(W_{t}^{P S}\right), \rightarrow V^{P S}=f\left(W_{t}^{P S}\right) \\
V N=f\left(W_{t}^{P S}\right)
\end{array}\right.
$$

The hourly schedule of the amount of electricity $W_{t}^{P S}$, consumed by an industrial enterprise from the power system per time $\mathrm{t}$ (hours) is determined using eqn (13):

$$
W_{t}^{P S}=W_{t}^{D}-W_{t}^{S D G}
$$

where $W_{t}^{D}$ is the hourly schedule of the total demand for electricity consumption of the electricity consumer $(\mathrm{kWh}) ; W_{t}^{S D G}$ is the electricity generation hourly schedule of a small-generation system (kWh).

The hourly schedule of the cumulative demand for electricity $W_{t}^{D}$ is formed as the sum of the power consumption of all power-consuming objects of the enterprise. At the same time, the hourly schedule $W_{t}^{P S}$, consumed by the industrial enterprise from the power system is the hourly difference between the demand for power consumption of all power consuming objects of the enterprise $W_{t}^{D}$ and the hourly power generation schedule $W_{t}^{S D G}$ by a smallgeneration system as shown in Fig. 1.

Taking into account the peculiarities of price-dependent electricity consumption management, the schedule of electricity generation by a small-generation system can be adjusted depending on the price parameters of the electricity market, thereby reducing the total cost of production and purchase of electricity and maximizing the company's profits.

\subsection{Formulation of the cost of natural gas purchase}

The cost of electricity generated by the system of small-distributed generation, working on natural gas is given by

$$
V_{m}^{S D G}=V_{m}^{\text {Gas }}-V_{m}^{\text {More }}
$$

where $V_{m}^{\text {Gas }}$ is the cost of purchased natural gas for electricity generation by a system of small-distributed generation for the settlement month (RUB); $V_{m}^{\text {More }}$ are the other costs that 


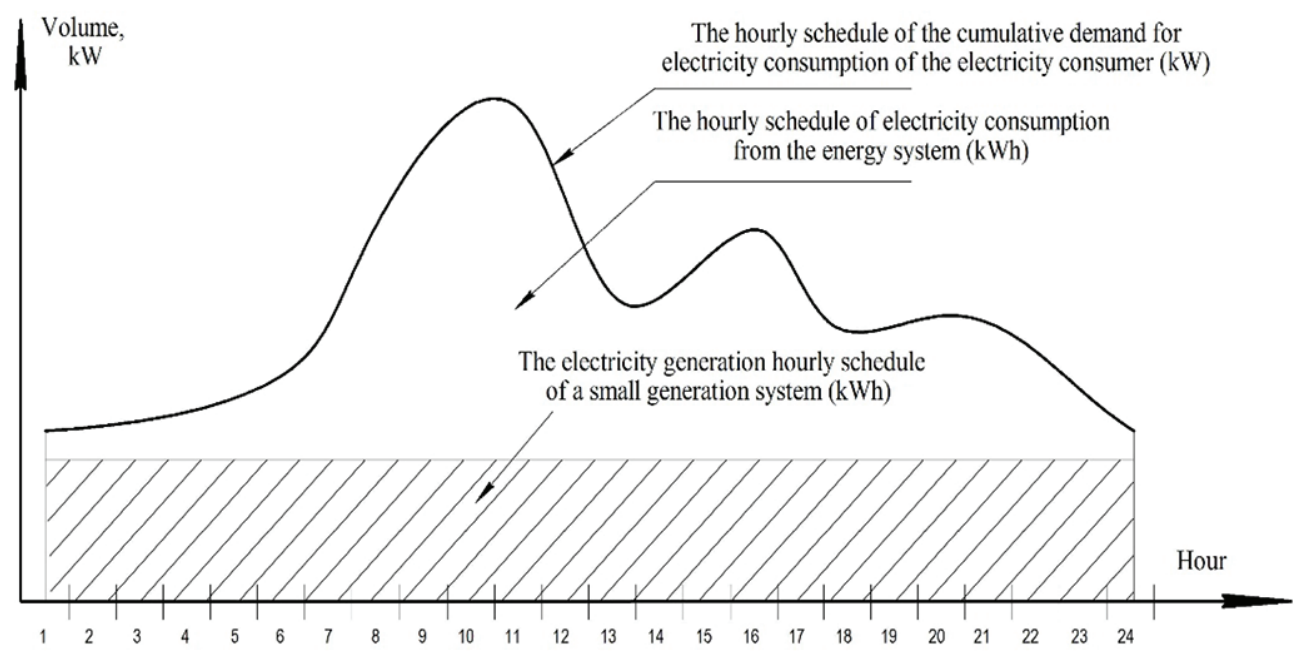

Figure 1: An example of the distribution of demand for electricity consumption of the enterprise between the hourly schedule of electricity generation by a smallgeneration system and the amount of consumption from the power system.

affect the cost of electricity generation by a system of small-distributed generation for the settlement month (RUB). This cost depends on the observance of the contractual limits on the gas offtake from the Unified Gas Supply System. Exceeding contractual limits may significantly increase the cost of generating electricity. Moreover, in many countries the limits on the gas offtake are more stringent than in Russia.

The schedule of electricity generation by the system of small-distributed generation is synchronous with the schedule of natural gas consumption from the Unified Gas Supply System as shown in Fig. 2; this is explained by the dependence of the generator load of a small-distributed generation system on the intensity of natural gas combustion as indicated by

$$
A_{\text {day }}^{\text {fact }}=f\left(W_{\text {day }}^{S D G}\right)
$$

where $A_{d a y}^{\text {fact }}$ is the volume of gas consumption by a system of small-distributed generation (thousand $\mathrm{m}^{3}$ ).

According to the terms of gas supply contracts by regional gas supply organizations, gas offtake during the calendar month is carried out when the condition of uniformity of daily consumption is met and the offtake volume is calculated by

$$
A_{\text {day_ } m_{-} x}^{\text {limit }}=A_{\text {month_x }}^{\text {limit }} / n_{\text {month_x }}^{\text {day }}
$$

where $A_{\text {month }}^{\text {limit } x}$ is the value of the daily limit of gas offtake per month $\times$ (thousand $\mathrm{m}^{3}$ ). $A_{\text {month }{ }_{-} x}^{\text {limit }}$ is the value of the month limit of gas offtake per month $\times\left(\right.$ thousand $\left.\mathrm{m}^{3}\right) . n_{\text {month }{ }_{-}}^{\text {day }}$ is the number of calendar days in a month $\mathrm{x}$ [18].

Figure 3 shows an example of daily gas offtake limits for a calendar month, the size of admissible gas offtake corridors and a schedule of gas consumption for a particular consumer. Apparently, the daily limits are constant during the settlement month of gas supply, 


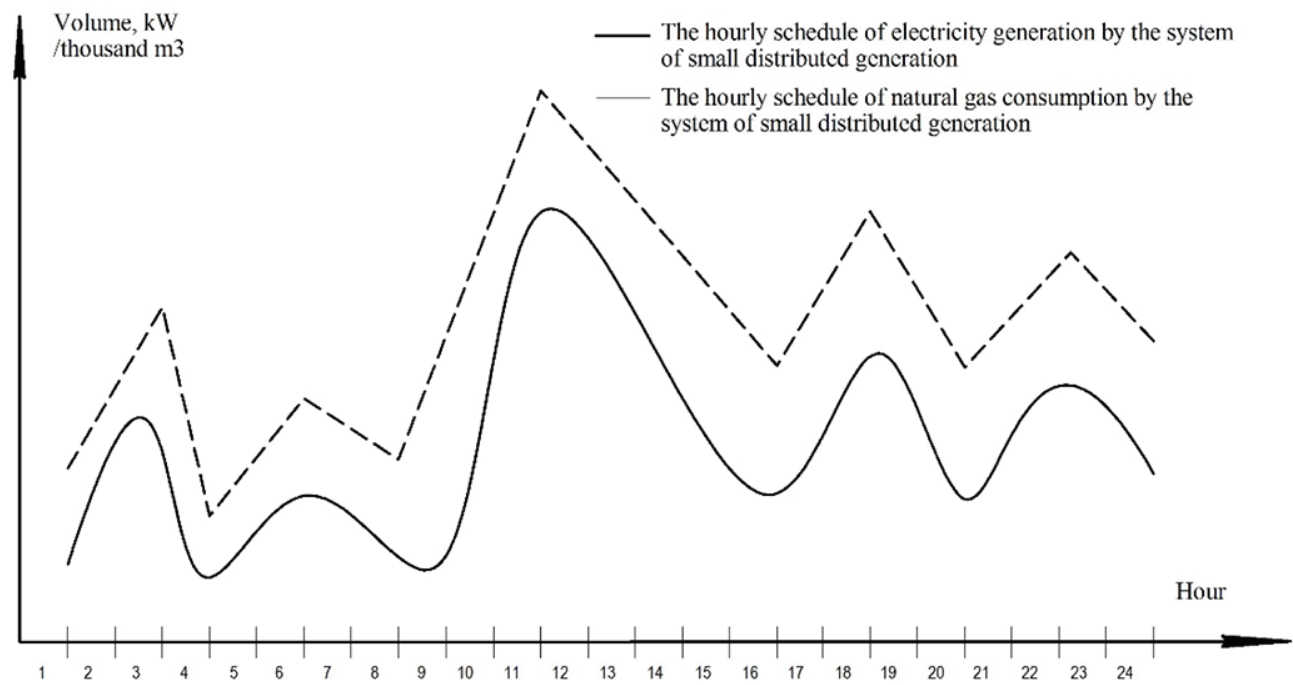

Figure 2: Configuration of electricity generation schedule by the system of small-distributed generation and the schedule of gas consumption for electricity generation.

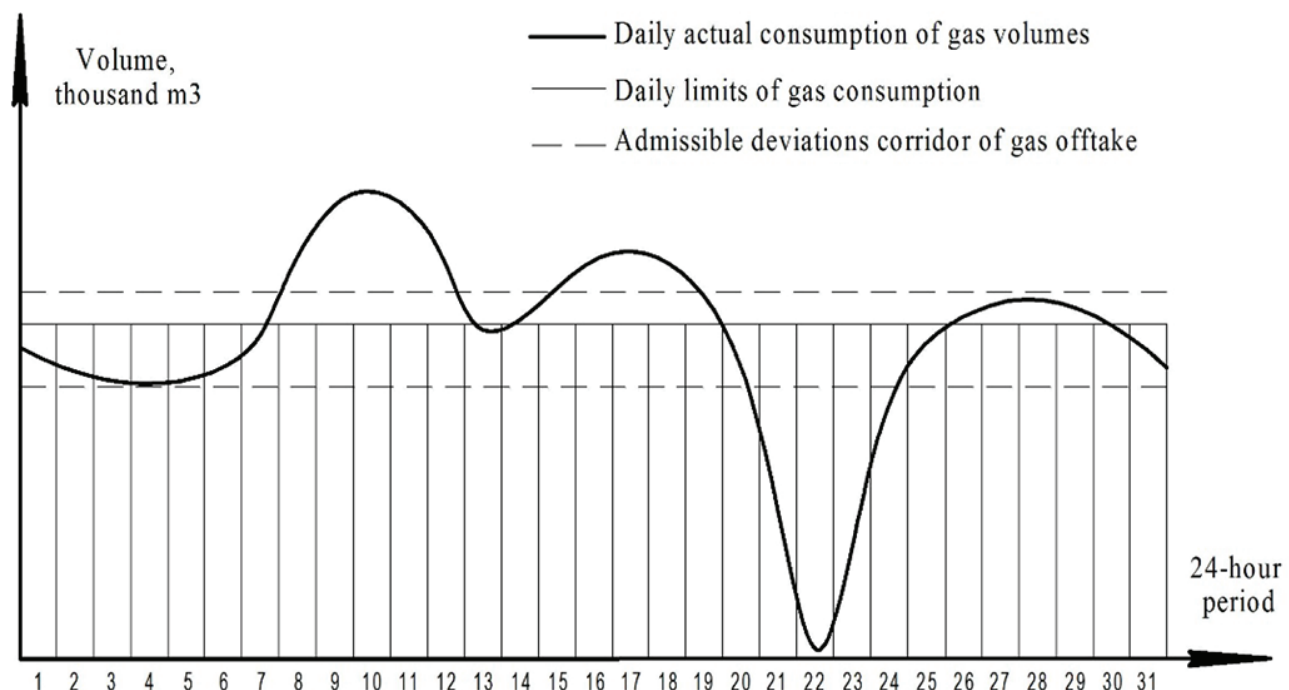

Figure 3: Example of daily limits and schedule of daily gas consumption by a large consumer.

with the volatile nature of actual consumption, which can go beyond the permissible corridor.

Thus, if the volume of gas consumption exceeds the daily limit, the consumption volume over the limit will be calculated using

$$
A_{\text {day_ } m_{-} x}^{\text {overimit }}=A_{\text {day }}^{\text {fact }}-A_{\text {day }_{y_{2} m_{-} x}}^{\text {limit }} \times 1.1
$$


where $A_{\text {day } m_{-} \text {ovelit }}^{\text {ovit }}$ is the daily gas consumption by the enterprise, paid with an overestimated coefficient (thousand $\mathrm{m}^{3}$ ); $A_{\text {day }}^{\text {fact }}$, daily actual consumption of gas by the consumer (thousand $\mathrm{m}^{3}$ ).

$$
\text { If } A_{d a y_{-} m_{-} x}^{\text {overlimit }}<0 \text {, then the value } A_{d a y_{-} m_{-} x}^{\text {overlimit }}=0 .
$$

In the case of gas consumption below the value of the established corridor of the average daily rate of gas offtake, the consumer bears penalties according to the volumes of under-consumption. At the same time, according to the rules of gas supply in the Russian Federation (RF) [19], when gas is not taken by buyers consuming up to 10,000 thousand $\mathrm{m}^{3}$ of gas per year, the volume of untaken gas is not paid.

Thus, if the amount of gas consumption is below the daily limit, the amount of consumption is paid with penalties according to

$$
A_{\text {day_ } m_{-} x}^{\text {non-selection }}=A_{\text {day_}_{m_{-} x}}^{\text {limit }} \times 0.8-A_{\text {day }}^{\text {fact }}
$$

where $A_{\text {day_ } m_{-} x}^{\text {non } m_{\text {section }}}$ is the amount of untaken volume of daily gas consumption by the enterprise that falls under penalty sanctions (thousand $\mathrm{m}^{3}$ ).

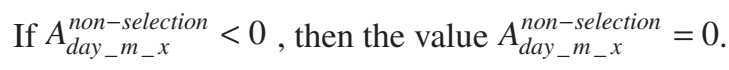

The cost of gas consumed in excess of the admissible gas offtake corridors for the settlement month is given by

$$
V_{\text {month_x }}^{\text {overlimit }}=\Sigma_{n}^{\text {month_x }} A_{\text {day }_{-} m_{-} x}^{\text {overlim }} \times T_{\text {gas }} \times K^{\text {overlimit }}
$$

where $V_{\text {month }}^{\text {overlimit }}$ is the cost of buying an excess gas volume in the month $\times$ (rub. per month). $\mathrm{T}_{\text {gas }}$ is the tariff for the supplied gas (rub. / thousand $\mathrm{m}^{3}$ ). $K^{\text {overlimit }}$ is the value of the exceeding coefficient [20].

$\checkmark \quad$ for the period from 15 April to 15 September: $K^{\text {overlimit }}=1.1$;

$\checkmark \quad$ for the period from 16 September to 14 April: $K^{\text {overlimit }}=1.5$.

A similar principle of flexible pricing for natural gas is applied in various countries of the world, such as the USA, Canada, Europe, and China. The principles of management proposed in this paper can be adapted to the processes of gas consumption by enterprises in many countries of the world.

Thus, the price-dependent management of the demand schedule for power consumption by covering a part of the demand with a small-generation system is the operational regulation of the small-distributed generation work. At the same time, it is important to remember that there is a probability of a situation when the tariff for electricity production by a system of small-distributed generation is higher than the tariff for electricity consumption from the power system due to non-observance of the limits for natural gas offtake by the enterprise, namely

$$
V_{m}^{P S} / W_{m}^{P S}<V_{m}^{S D G} / W_{m}^{S D G}
$$

At the same time, as can be seen from eqn (19), the limits on the gas offtake depend only on the daily period, and the price-dependent demand management for electricity consumption is made with hourly discretion, which provides the possibility of managing the intra-day 


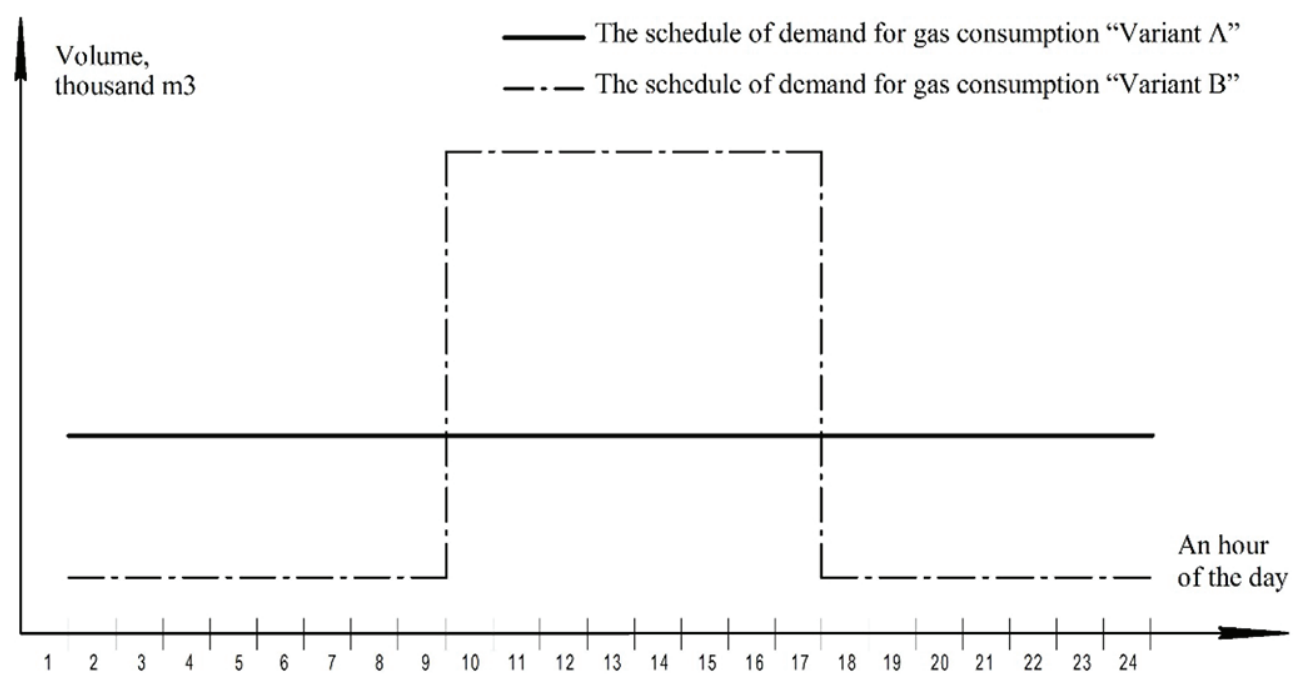

Figure 4: Example of hourly demand for gas offtake schedules.

volatility of electricity generation by a small-generation system, with the condition of not exceeding the limits for gas offtake in terms of the day.

Figure 4 shows an example of two hourly schedules variants of demand for natural gas consumption in terms of the day. On the schedule 'A', the demand is uniform at every hour of the day, and hourly volumes of gas consumption on the schedule 'B' vary, while in the period from 10 a.m. to 5 p.m. the gas consumption volumes exceed the 'A' schedule, in other periods it is significantly lower. Despite the difference in the hourly volumes of demand for gas consumption in variants ' $A$ ' and ' $B$ ', the volumes of daily consumption are equivalent and the gas offtake under variant ' $\mathrm{B}$ ' is within the limits and is paid at base tariffs without penalty.

Thus, the volatility management of the electricity generation by a system of small-distributed generation makes it possible to use price-dependent management of the cost of purchasing electricity from the power system without exceeding the current limits for the gas offtake, and therefore reduce costs for the purchase of electricity without increasing the cost of producing it by a small-generation system.

\section{MODEL OF THE PRICE-DEPENDENT DEMAND MANAGEMENT}

Taking into account the peculiarities of pricing and rules for the electricity and natural gas purchase, the authors developed a model of the price-dependent demand management for power consumption, integration with a system of small-distributed generation. A flow chart of this model is presented in Fig. 5.

The model consists of a series of successively implemented blocks. In the beginning, the distribution of electricity generation volumes by a small-generation system and electricity consumption from the power system is planned for different management periods, divided by a day, week, month, quarter, etc.

The basis of the model is the forecast of hourly electric power consumption schedule of the enterprise for various management periods, the correction of which is achieved through the modeling of the cost of electricity purchased by the consumer from the power system, by developing and analyzing different variants for covering the cumulative demand for power 


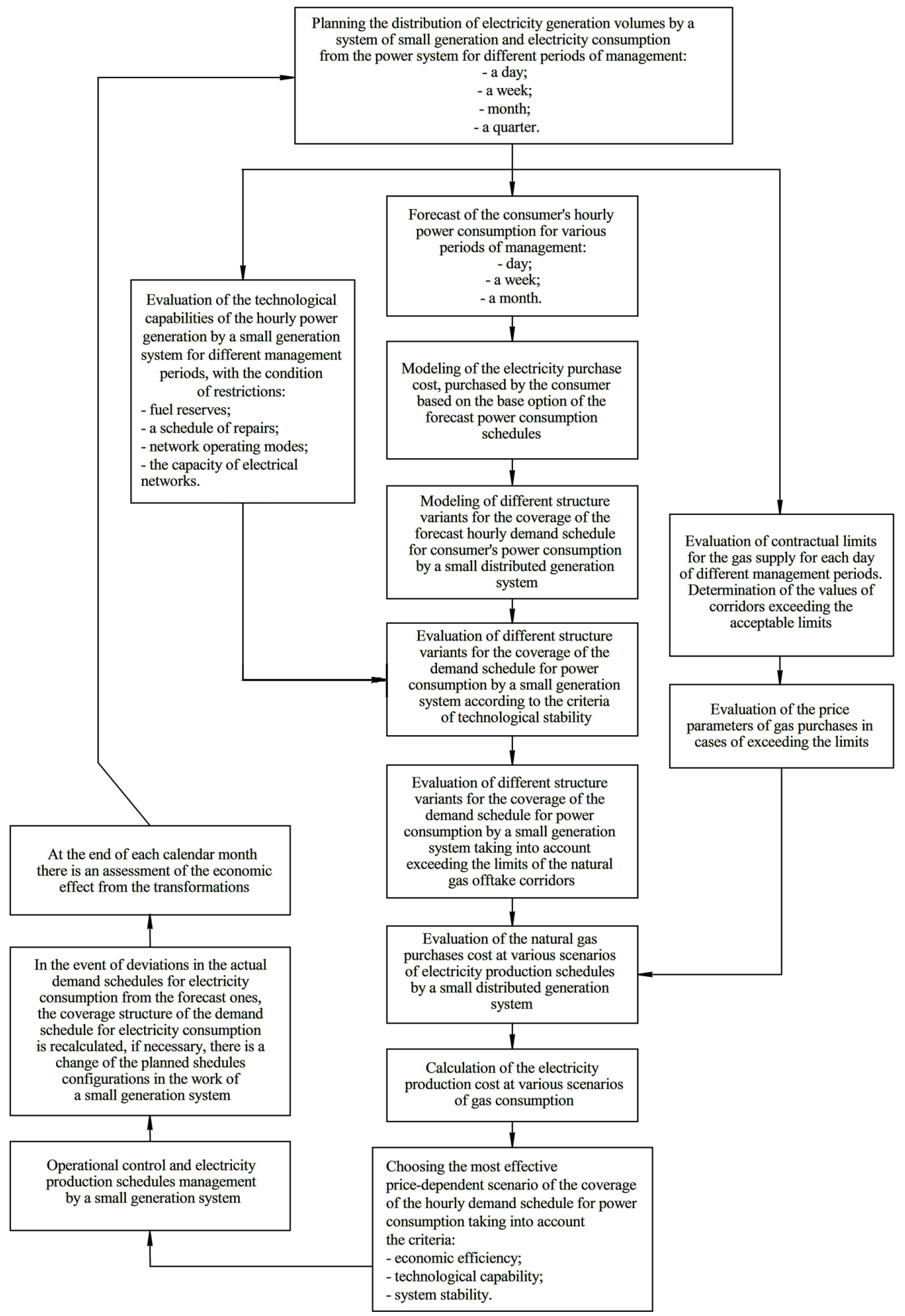

Figure 5: The model of price-dependent demand management for electricity and natural gas consumption based on the integration with a system of small-distributed generation. 
consumption by a system of small-distributed generation [14]. An obligatory link is the analysis of technological opportunities for hourly electricity generation by a small-generation system for the management periods under consideration, including restrictions such as availability of fuel reserves, a schedule of repairs, network operating modes and the capacity of electrical networks. The result of the analysis is the modeling of different structure variants for the coverage of the hourly demand schedule for consumers' power consumption, taking into account the identified technological limitations for different management periods.

In parallel, the contractual limits for the gas supply for each day are calculated, the values of corridors exceeding the acceptable limits are defined and the price parameters of gas purchases in cases of exceeding the limits are evaluated. Taking into account the cost parameters of gas purchase, for different structure variants of the coverage of the demand schedule for power consumption by a small-generation system, the cost of gas and the cost of generating electricity by a small-generation system for each scenario are calculated.

The next step is to estimate the cost parameters of electricity consumption for various scenarios of the hourly demand coverage structure and a choice is made of the optimal variant according to the criteria of economic efficiency, technological capability and system stability.

After determining the optimal variant for covering the hourly demand schedule for electricity consumption and putting it into operation, operational control and management of electricity generation schedules by a small-generation system is carried out. In the event of deviations in the actual demand schedules for electricity consumption from the forecast ones, the efficiency of the variants for the coverage structure of the demand schedule for electricity consumption is recalculated, and, if necessary, the work of the small-generation system is corrected. At the end of each calendar month (the settlement period for the purchase of electricity in the wholesale and retail markets), an economic effect is estimated from the transformations carried out.

\section{EXPERIENCE FROM A PRACTICAL APPLICATION OF THE PRICE-DEPENDENT DEMAND MANAGEMENT MODEL}

Table 2 presents the results of calculating the cost of purchasing electricity and natural gas for three different options of demand schedules for energy resources from the side of the enterprise - 'A', 'B' and 'C'.

Table 2: Economic effect predicted from the implementation of the developed model.

\begin{tabular}{|c|c|c|c|c|c|}
\hline No. & Parameter & Unit & 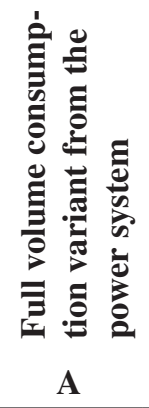 & 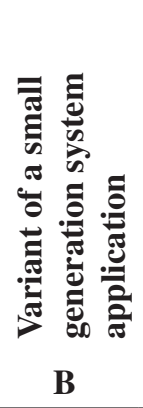 & 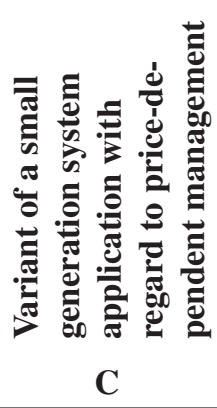 \\
\hline 1 & $\begin{array}{l}\text { Hourly schedule of daily electricity } \\
\text { demand }\end{array}$ & $\mathrm{kWh}$ & 36,000 & 36,000 & 36,000 \\
\hline 2 & $\begin{array}{l}\text { The volume of electricity generation } \\
\text { by a small-generation system per day }\end{array}$ & $\mathrm{kWh}$ & 0 & 10,000 & 10,000 \\
\hline
\end{tabular}




\begin{tabular}{|c|c|c|c|c|c|}
\hline 3 & $\begin{array}{l}\text { The amount of electrical energy pur- } \\
\text { chased from the power system per day }\end{array}$ & $\mathrm{kWh}$ & 36,000 & 26,000 & 26,000 \\
\hline 4 & $\begin{array}{l}\text { The value of daily limits on gas con- } \\
\text { sumption }\end{array}$ & $\mathrm{m}^{3}$ & 5,000 & 5,000 & 5,000 \\
\hline 5 & $\begin{array}{l}\text { The value of daily gas consumption } \\
\text { by a small-generation system }\end{array}$ & $\mathrm{m}^{3}$ & 0 & 4,000 & 4,000 \\
\hline 6 & $\begin{array}{l}\text { The amount of over-limit gas con- } \\
\text { sumption by a small-generation } \\
\text { system }\end{array}$ & $\mathrm{m}^{3}$ & 0 & 0 & 0 \\
\hline 7 & Average electricity purchase tariff & $\begin{array}{l}\mathrm{RUB} / \\
\mathrm{kWh}\end{array}$ & 1.15 & 1.15 & 1.04 \\
\hline 8 & Electric capacity consumption volume & $\begin{array}{l}\mathrm{kWh} / \\
\text { month }\end{array}$ & 1,700 & 1,225 & 970 \\
\hline 9 & Average tariff for electric capacity & $\begin{array}{l}\mathrm{RUB} / \\
\mathrm{kWh}\end{array}$ & 0.92 & 0.92 & 0.76 \\
\hline 10 & $\begin{array}{l}\text { Base of payment of services for the } \\
\text { maintenance of electrical networks }\end{array}$ & $\begin{array}{l}\mathrm{kWh} / \\
\text { month }\end{array}$ & 2,000 & 1,440 & 1,140 \\
\hline 11 & $\begin{array}{l}\text { Tariff for payment of services for the } \\
\text { maintenance of electrical networks }\end{array}$ & $\begin{array}{l}\text { RUB/ } \\
\mathrm{kWh}\end{array}$ & 0.97 & 0.97 & 0.76 \\
\hline 12 & $\begin{array}{l}\text { Tariff for payment of technological } \\
\text { consumption in electrical networks }\end{array}$ & $\begin{array}{l}\text { RUB/ } \\
\mathrm{kWh}\end{array}$ & 0.14 & 0.14 & 0.14 \\
\hline 13 & $\begin{array}{l}\text { General tariff for the purchase of } \\
\text { electricity }\end{array}$ & $\begin{array}{l}\text { RUB/ } \\
\mathrm{kWh}\end{array}$ & 3.18 & 3.18 & 2.70 \\
\hline 14 & $\begin{array}{l}\text { Tariff for power generation by a } \\
\text { small-generation system }\end{array}$ & $\begin{array}{l}\text { RUB/ } \\
\mathrm{kWh}\end{array}$ & 2.92 & 2.92 & 2.92 \\
\hline 15 & $\begin{array}{l}\text { The cost of electricity purchased from } \\
\text { the power system per day }\end{array}$ & RUB & 114,480 & 82,680 & 70,200 \\
\hline 16 & $\begin{array}{l}\text { The cost of electricity generated by a } \\
\text { small-generation system }\end{array}$ & RUB & 0 & 29,200 & 29,200 \\
\hline 17 & $\begin{array}{l}\text { The purchase price of natural gas } \\
\text { within the contractual limits }\end{array}$ & $\begin{array}{l}\mathrm{RUB} / \\
\mathrm{m}^{3}\end{array}$ & 0 & 4.50 & 4.50 \\
\hline 18 & $\begin{array}{l}\text { The purchase price of natural gas over } \\
\text { contractual limits }\end{array}$ & $\begin{array}{l}\mathrm{RUB} / \\
\mathrm{m}^{3}\end{array}$ & 0 & 6.75 & 6.75 \\
\hline 19 & $\begin{array}{l}\text { The total cost of natural gas purchase } \\
\text { by a small-generation system }\end{array}$ & RUB & 0 & 18,000 & 18,000 \\
\hline 20 & $\begin{array}{l}\text { The total cost of electricity consump- } \\
\text { tion per day }\end{array}$ & RUB & 114,480 & 111,880 & 99,400 \\
\hline 21 & $\begin{array}{l}\text { Average cost of electricity consump- } \\
\text { tion }\end{array}$ & $\begin{array}{l}\mathrm{RUB} / \\
\mathrm{kWh}\end{array}$ & 3.18 & 3.11 & 2.76 \\
\hline 22 & $\begin{array}{l}\text { Average savings due to the use of a } \\
\text { distributed generation system }\end{array}$ & $\begin{array}{l}\mathrm{RUB} / \\
\mathrm{kWh}\end{array}$ & 0.00 & 0.07 & 0.42 \\
\hline
\end{tabular}




\begin{tabular}{llcccc}
\hline 23 & $\begin{array}{l}\text { Total savings from using a distributed } \\
\text { generation system per day }\end{array}$ & RUB & 0.00 & 2,600 & 15,080 \\
24 & $\begin{array}{l}\text { Relative savings due to the use of a } \\
\text { distributed generation system }\end{array}$ & $\%$ & $0.0 \%$ & $2.3 \%$ & $13.2 \%$ \\
\hline
\end{tabular}

'A' - the amount of electricity required by the enterprise is fully purchased from the power grid;

'B' - a part of the electricity demand is covered by a small-generation system, without applying price-dependent management methods;

' $\mathrm{C}$ ' - a part of the electricity demand is covered by a small-generation system, using price-dependent management methods.

Comparing options ' $\mathrm{A}$ ' and ' $\mathrm{B}$ ' shows that the effect of using small-distributed generation is 7 kopecks per $1 \mathrm{kWh}$, or $2.3 \%$ of the total cost of electricity without the use of pricedependent management. Savings in the case of price-dependent management methods are 42 kopecks per $1 \mathrm{kWh}$, or $13.2 \%$ of the total cost of electricity.

\section{CONCLUSION}

The main points of conclusion from the results of the study can be stated as follows:

1. Application of the price-dependent electricity consumption technology in industrial enterprises with small-distributed generation systems makes the efficiency increase from using autonomous power-generating systems possible by reducing the total cost of purchased electricity, reducing the payback period of investments in the creation of small-distributed generation systems, expanding the number of serviced facilities. It also promotes growth of the general efficiency of electricity consumers' functioning using small-distributed generation systems.

2. The economic effect obtained from the joint use of the price-dependent electricity consumption technology and distributed generation systems is formed by lowering the average tariff for the electricity purchase from the power system and, consequently, the total amount of electricity consumption costs for all its components (electric energy cost, electric capacity cost and cost of the services for electricity transmission).

3. The price-dependent consumption of natural gas consumed by the system of smalldistributed generation in the process of electricity generation eliminates the risk of its over-limit consumption, and therefore, improves the efficiency of the model of pricedependent electricity consumption.

4. The authors' model of price-dependent demand management for electricity and natural gas consumption, developed on the basis of integration with a system of smalldistributed generation, allows large consumers of electric power to reduce the cost of paying for energy resources and significantly increase the economic efficiency of using small-distributed generation systems.

5. The effectiveness of the application and the practical importance of the developed pricedependent management model are confirmed by the results of its appraisal carried out by the authors on the basis of an industrial enterprise. As a result of the application of the price-dependent electricity consumption management in parallel with the use of smalldistributed generation, it was possible to achieve cost savings of $13.2 \%$, which is almost 
six times higher than the savings obtained only with the use of small-distributed generation in Russia. The obtained results underline the relevance and practical significance of the research results for large electricity consumers in Russia and other countries of the world.

6. The authors' model of price-dependent electricity consumption management based on integration with a system of small-distributed generation can be adapted to the use by various types of electricity consumers that purchase electricity on the energy markets of various countries around the world.

7. The increase in energy cost savings from the use of the system of small-distributed generation when applying the proposed methods of price-dependent management (from $2.3 \%$ to $13.2 \%$ in the framework of the considered example) emphasizes the relevance and practical significance of the research results for modern science and practice.

8. When using other types of alternative energy sources, such as solar generation, wind generation, solid fuel power plants, price-dependent management methods can also be used, but they need to be adapted taking into account the specifics of pricing for these electricity sources.

\section{ACKNOWLEDGEMENT}

The work was supported by Act 211 Government of the Russian Federation, contract No 02.A03.21.0011.

\section{REFERENCES}

[1] Ma, S. \& Urpelainen, J., Distributed power generation in national rural electrification plans: An international and comparative evaluation. Energy Research \& Social Science, 44, pp. 1-5, 2018.

[2] Yang, Y., Hefley, W.E. \& Rajgopal, J., The economics of distributed power: A Marcellus Shale case study. Computers \& Industrial Engineering, 113, pp. 558-569, 2017.

[3] Chae, W., Kim, J., Cho, J. \& Park, J., Optimal interconnection device for distributed energy resources of customer. In 2012 3rd IEEE International Symposium on Power Electronics for Distributed Generation Systems (PEDG), pp. 878-882, 2012.

[4] Dulău, L.I. \& Bică, D., Influence of distributed generators on power systems. Procedia Engineering, 181, pp. 791-795, 2017.

[5] Mehigan, L., A review of the role of distributed generation (DG) in future electricity systems. Energy, 163, pp. 822-836, 2018.

[6] Popova, S.N. \& Potekhina, N.V., Prospects and limitations of the development of distributed power in the Russian electricity market. Society: Politics, Economics, Law, 12, pp. 93-95, 2016.

[7] Klimovets, O.V., Estimation of economic efficiency of power supply of an industrial enterprise using distributed generation. Bulletin of the Russian Economic University in honour of G.V. Plekhanov, 86(2), pp. 140-144.

[8] Development of distributed generation. Analytical report of the Moscow School of Management Skolkovo Energy Center. p. 38, 2012. [electronic resource] URL: http:// smartmetering.ru/common/upload/SEneC_Distributed_Generation.pdf

[9] Ackermann T., Andersson G. \& Söder, L., Distributed generation: A definition. Electric Power Systems Research, 57(3), pp. 195-204, 2001. 
[10] Ya. A., Frolova, Y.A., Rusina, G. \& Armeev, D.V., Optimization of power systems modes with distributed generation on-line. New in the Russian Electric Power Industry, 11, pp. 34-41, 2017.

[11] Gitelman, L.D., Ratnikov, B.E. \& Kozhevnikov, M.V., Electricity demand management: adaptation of foreign experience in Russia. Effective Anti-Crisis Management, 76(1), pp. 84-89, 2013.

[12] Solovyova, I.A. \& Dzyuba, A.P., Management of costs for power consumption of industrial enterprises on the basis of the electric load schedules optimization model Izvestiya of the Tula State University. Economic and Legal Sciences, (1-1), pp. 165-174, 2017.

[13] Dzyuba, A.P. \& Solovyova, I.A., Integration of small distributed power systems into the price-dependent demand management for power consumption model. Problems of Economics and Management of the Oil and Gas Complex, 5, pp. 39-49, 2018.

[14] Energy Prices and taxes 2017 IEA, Report of International Energy Agency, p. 422, URL: http://data.iea.org//payment/products/111-energy-prices-and-taxes-quarterly.aspx

[15] Resolution of the Government of the Russian Federation of N 1172, On Approval of the Rules for the Wholesale Electricity and Capacity Market, December 27, 2010. [electronic resource] URL: http://consultant.ru/document/cons_doc_LAW_112537/

[16] Agreement on accession to the trading system of the wholesale electricity (capacity) market, Appendix 13.2. Regulation on determining the volume of purchase and sale of capacity on the wholesale market, [electronic resource] URL: https://np-sr.ru/ru/regulation/joining/reglaments/1978

[17] The planned peak hours of the United Power Grid of Russia on the 2018 months, [electronic resource] URL: http://so-ups.ru/fileadmin/files/company/markets/2018/ pik_chas2018.pdf

[18] Resolution of the Government of the Russian Federation No. 333 of (Edited on December 31, 2010), On improving state regulation of gas prices, May 28, 2007. [electronic resource]. URL: http://consultant.ru/document/cons_doc_LAW_55732/ (reference date: December 24, 2017).

[19] Resolution of the Government of the Russian Federation of No. 566, On Amendments to Certain Acts of the Government of the Russian Federation Concerning Gas Sales in the Russian Federation, [electronic resource], June 19, 2014, URL: http://static.government.ru/media/files/41d4ea45da756d8377a5.pdf (reference date: December 24, 2017). 